\title{
ARTYKUŁY
}

Klio. Czasopismo poświęcone dziejom Polski i powszechnym

PL ISSN 1643-8191, t. 26 (3)/2013, s. 5-22

(c) $($ ) $\odot$

DOI: http://dx.doi.org/10.12775/KLIO.2013.031

Danuta Musiae

(Toruń)

\section{Kobieta i mężczyzna w świecie antycznym: uwagi o starych sporach i nowych oczekiwaniach}

$\mathrm{H}$

istoria kobiet długo torowała sobie drogę do szkolnych programów. W Europie powoli staje się integralnym składnikiem edukacji historycznej. W najszerszym zakresie dzieje się tak we Francji, tam też toczy się bardzo ożywiona dyskusja o treściach i sposobach jej nauczania, która odzwierciedla dylematy współczesnej historiografii związane z dyscypliną nazywaną umownie „historia kobiet”. Jest to termin wygodny, aczkolwiek bywa dzisiaj kontestowany z powodów, o których wspominam w dalszej części artykułu. Przewagę zyskuje pogląd, że powinniśmy mówić o relacjach między obydwiema płciami rozumianymi jako grupy społeczne, ponieważ „kobiety i mężczyźni, wspólnie, dzień po dniu konstruowali społeczeństwo, w którym żyli”. Tym stwierdzeniem zaczynają narrację autorzy jednego z francuskich podręczników szkolnych - wiele wyjaśnia tytuł tej publikacji, która chronologicznie obejmuje starożytność i średniowiecze: Kobiety i mężczyźni w historii. Wspólna przesztoścí .

${ }^{1}$ C. Marissal, É. Gubin, C. Jacques, A. Morelli, Femmes \& hommes dans l'histoire. Un passé commun. Antiquité et Moyen Âge, Naumur 2013. 
Od roku szkolnego 2012/2013 w polskich szkołach obowiązuje podstawa programowa, w której problematyka związana z rolą kobiet w historii została zasygnalizowana $\mathrm{w}$ odrębnym punkcie. W ramach przedmiotu historia i społeczeństwo (IV etap edukacyjny) pod hasłem „dziedzictwo epok" proponowany jest blok dziewięciu (fakultatywnych) wątków tematycznych. Jednym z nich jest: „Kobieta i mężczyzna, rodzina”. Bardzo ogólne wskazówki co do treści merytorycznych realizowanych w ramach tego tematu dopuszczają dużą swobodę w doborze problemów szczegółowych. Czas pokaże, jakimi treściami zostaną wypełnione hasła problemowe zarysowane w Podstawie programowej: obrazy miłości, rola kobiety i mężczyzny, model rodziny, oraz w jakim zakresie odzwierciedlenie na zajęciach znajdą problemy analizowane przez współczesną historiografię.

W Polsce historia kobiet nigdy nie była traktowana jako odrębna dyscyplina historyczna. Niewielka jest też tradycja badań, na co zwraca uwagę Andrzej Radzimiński we wstępie do swojej książki Kobieta w średniowiecznej Europie (2012), wskazując na ogrom literatury przedmiotu, ale niestety nie w języku polskim. Zapewne zaległości będą stopniowo nadrabiane, czego symptomem są coraz liczniej organizowane konferencje naukowe poświęcone różnym aspektom kondycji kobiet w przeszłości.

Celem mojego artykułu jest przybliżenie dyskusji toczonych od lat siedemdziesiątych ubiegłego wieku, które doprowadziły do ukształtowania pewnych modeli pisania o roli kobiet w perspektywie historycznej. Wybór wątków i lektur jest subiektywny i w żadnym razie nie pretenduje do kompletności, ale nie wydaje mi się, aby inne rozwiązanie było możliwe wobec bogactwa problematyki. Zainteresowania zawodowe kierują moją uwagę przede wszystkim ku treściom z zakresu historii Grecji i Rzymu, stąd świat antyczny w tytule, choć część cytowanych przez mnie prac bezpośrednio nie dotyczy tej epoki. Moim zdaniem wiele sygnalizowanych przeze mnie kwestii nie wiąże się bezpośrednio z konkretną epoką historyczną. Poza tym wszystkie problemy związane z rozwojem historii jako nauki dotyczą również historii starożytnej, która nie jest przecież „metodologiczną wyspą” i bez metod wypracowanych przez inne dyscypliny i specjalności nie mogłaby się rozwijać ${ }^{2}$. Ponadto starożytnicy, często chętniej niż znawcy innych

${ }^{2}$ Zob.: D. Musiał, O perspektywach badań nad antykiem, „Klio. Czasopismo poświęcone dziejom Polski i powszechnym" 2001, t. 1, s. 5-14. 
epok, sięgali do doświadczeń nauk społecznych, stąd uniwersalny charakter wielu opinii formułowanych w ich pracach.

Historia kobiet jako autonomiczny temat badawczy ma w historiografii XX w. swoją własną, niezbyt długą tradycję. Jej początki wiążą się z narodzinami ruchów feministycznych na przełomie lat sześćdziesiątych i siedemdziesiątych, najpierw w Stanach Zjednoczonych, a nieco później w Europie, przede wszystkim we Francji.

Nie znaczy to oczywiście, że przed tą epoką kontestacji kobiety w historiografii były nieobecne, ale w pierwszej połowie XX w. teksty poświęcone wyłącznie kobietom były rzadkie i zwykle dotyczyły ich sytuacji prawnej. Z czasem pisanie o kobietach antyku zdominował specyficzny, nadal bardzo popularny, rodzaj biografistyki. Zainteresowanie autorów i czytelników budzą kobiety ambitne, z impetem wkraczające do męskiego świata, jak Kleopatra, królowa Egiptu, czy rzymskie cesarzowe, przede wszystkim z dynastii julijsko-klaudyjskiej ${ }^{3}$. Gillian Clark w krótkim podsumowaniu „obecności” kobiet $\mathrm{w}$ jednym z najważniejszych periodyków starożytniczych, wychodzącym od 1931 r. „Greece \& Rome”, zauważyła, że pierwszy tekst mający kobiety w tytule pojawił się w 1942 r. (H. G. Mullens) i - jakżeby inaczej - nosił tytuł The Women of the Ceasars. Kolejny (1945) ukazal się pod tytułem Women in Roman Life and Letters (F. E. Adcock). „W życiu i w literaturze" - takie tytuły spotyka się bardzo często w bibliografiach prac o kobietach antyku. Ich autorzy chętnie, często z przesadnym zaangażowaniem, przyjmują punkt widzenia pisarzy antycznych, powtarzając za nimi nawet najmniej prawdopodobne oskarżenia o wszelkie możliwe występkí ${ }^{4}$. Przykładem postaci, którym od starożytności towarzyszy czarna legenda, są dwie żony cesarza Klaudiusza - Waleria Messalina i Agryppina Młodsza. Innym typem bohaterek są kobiety identyfikowane jako towarzyszące mężczyznom matki i żony: Kornelia, matka Grakchów, Liwia, żona Augusta.

${ }^{3}$ Do tej kategorii należy nadal chętnie czytana książka A. Krawczuka, Poczet cesarzowych rzymskich, Warszawa 1998 i ciekawsza, choć również bardzo tradycyjna w ujęciu kobiecej problematyki, popularna praca I. Bieżuńskiej-Małowist, Kobiety antyku: Talenty, ambicje, namiętności, Warszawa 1993.

${ }^{4}$ G. Clark, Silence and Women in „Greece \& Rome”, „Greece \& Rome” 2003, vol. 50, s. 132-134; http://dx.doi.org/10.1093/gr/50.suppl_1.132. 
„Zwykłe kobiety” pojawiają się przede wszystkim w kontekście rozważań o małżeństwie i rodzinie ${ }^{5}$. W przeszłości za każdym razem podkreślano prawne upośledzenie kobiet, co miało uzasadniać ich nieuwzględnianie przy omawianiu zagadnień z historii politycznej i społecznej. Dla ilustracji posłużę się cytatem z dostępnej polskiemu czytelnikowi książki Roberta Flacelière’a o życiu codziennym w Grecji, której oryginalne wydanie ukazało się w 1959 r. Flacelière w rozdziale „Kobieta, małżeństwo rodzina" pisał, że

obywatelki ateńskie, podobnie jak niewolnicy, nie posiadały samodzielności prawnej ani żadnych praw politycznych [...]. Zamężna Atenka, zamknięta w domu przynajmniej tu rządziła ciesząc się autorytetem, jeżeli tylko jej pan i władca nie sprzeciwiał się temu [...]. Mąż zresztą, wystarczająco zajęty poza domem pracą w polu lub polowaniem bądź wykonywaniem swego zawodu i uczestniczeniem w życiu politycznym oraz sądowym miasta, najczęściej czuł się zmuszony pozostawić żonie kierowanie domem wedle jej woli ${ }^{6}$.

To przekonanie o pełnym ubezwłasnowolnieniu Atenek epoki klasycznej jest nadal trwałym składnikiem podręcznikowych informacji.

W przeszłości podejmowano również próby całościowego przedstawienia historii kobiet. Przykładem jest chociażby Histoire mondiale de la Femme (Powszechna historia kobiety), której pierwszy tom, poświęcony starożytności, ukazał się w 1965 r. Praca była nowatorska w tym sensie, że legitymizowała kobietę jako obiekt badań. Pierre Grimal napisał we wstępie, że najważniejszą kwestią z „emancypacji” jest przywrócenie kobiecie miejsca w historii ${ }^{7}$. Znacząca jest przy tym liczba pojedyncza w tytule tej publikacji, wskazująca, że chodzi kobietę jako swego rodzaju abstrakcyjny byt pozaczasowy, czemu nie towarzyszyła żadna metodologiczna refleksja.

${ }^{5}$ Jeżeli chodzi o problematykę greckiej rodziny, polski czytelnik ma do dyspozycji interesującą monografię A. Wypustka, Życie rodzinne starożytnych Greków, Wrocław 2007.

${ }^{6}$ R. Flacelière, Życie codzienne w Grecji za czasów Peryklesa, Warszawa 1985, s. 51.

7 Histoire mondiale de la Femme, dir. P. Grimal, t. 1:, Préhistoire et Antiquité par L. R. Nougier, J. Vercoutter, J. Bottero, J. Danmanville, R. Flacelière, P. Grimal, Paris 1965. 
Charles T. Seltmann we wstępie do książki o kobietach w starożytności napisał:

Kobiety. Nie ma żadnej potrzeby, aby je definiować. Jesteśmy zawsze z nimi, a one z nami. Na szczęście ${ }^{8}$.

Dwadzieścia lat później historyczki feministki uznają zdefiniowanie takich pojęć jak „kobieta” i „kobiecość” za jeden z ważniejszych celów swoich studiów.

Rewolucyjne zmiany w podejściu do problematyki kobiet przyniosła z jednej strony historiografia feministyczna, z drugiej zaś - antropologia kulturowa, której metodologię historycy zaczęli szerzej wykorzystywać w drugiej połowie XX w. Trzeba jednak pamiętać, że feminizm (pomijam kwestię natury i wewnętrznego zróżnicowania różnych feminizmów, jako nieistotną dla moich rozważań) koncentrował się początkowo na współczesności i był nastawiony przede wszystkim na praktykę. U jego podstaw leżało bowiem przekonanie, że „kobietom jako kobietom, na podstawie samej różnicy płci w stosunku do mężczyzn, dzieje się w społeczeństwie krzywda”; ten stan rzeczy musi ulec zmianie, ale dokonać jej muszą same kobiety9. Potrzebowały do tego intelektualnych narzędzi, których dostarczyć miały tzw. women studies rozwijające się na amerykańskich uniwersytetach już od lat sześćdziesiątych. Zajmowano się na nich początkowo przede wszystkim teoretycznymi aspektami równouprawnienia kobiet, równością szans itp. Kwestia historii kobiet była traktowana marginalnie, również dlatego, że pierwsze pokolenie kreatorek studiów kobiecych tworzyły przedstawicielki nauk społecznych (politologii, socjologii, filozofii), zwykle głęboko zaangażowane w spory ideologiczne, ale niespecjalnie dostrzegające znaczenie - zwłaszcza odległej - przeszłości dla zrozumienia kondycji kobiety współczesnej. Naturalną koleją rzeczy ich historyczne zainteresowania dotyczyły, co najwyżej, narodzin nowoczesności. Z czasem jednak pojawiło się dążenie do poznania źródeł kobiecej opresji, co spowodowało rozwój historiografii feministycznej. Na początku jej podstawowym celem było wypełnianie

${ }^{8}$ Ch. T. Seltmann, Women in Antiquity, London 1956.

9 K. Ślęczka, Feminizm, Katowice 1999, s. 12. 
luki w historii akademickiej, która od chwili swego powstania nie traktowała kobiet jako problemu badawczego. Mamy więc do czynienia z „historią kompensacyjną". Termin ten pojawia się w tekście, który (w dużym skrócie) podsumowuje pretensje wysuwane przez środowiska feministyczne wobec historiografii ${ }^{10}$.

Jego autorka, Monika Bobako, obwinia historię uniwersytecką stawiającą w XIX w. pierwsze kroki o przyjęcie obrazu przeszłości zdominowanego przez historie narodowe. W centrum zainteresowania historyków znalazły się polityczno-militarne dzieje hierarchicznie zorganizowanych wspólnot narodowych i dokonania stojących na ich czele mężczyzn. Hierarchia obowiązująca we wspólnotach narodowych odtwarzała struktury patriarchalne oparte na ścisłym podziale ról i rozgraniczeniu stref na publiczną i prywatną. Kobietom przypisano główną rolę w zapewnieniu narodowi „biologicznej reprodukcji i przekazywaniu tradycji” i zamknięto je w strefie prywatnej. W odniesieniu do przeszłości jedyną dostępną formą symbolicznego „zadośćuczynienia” za krzywdę mogło być tylko przywrócenie kobietom należnego im miejsca w nauce o dziejach. Trudno się z tą diagnozą nie zgodzić, ale warto ją nieco uściślić.

Nie ulega wątpliwości, że w spadku po XIX w. nasza dyscyplina przejęła przekonanie, że historia jest sprawą mężczyzn. To oni działali, wymyślali, tworzyli, a przede wszystkim - to dla nich była zastrzeżona instytucjonalna władza we wszelkich jej postaciach. $\mathrm{Z}$ tego powodu w dyskursie o kobietach ogromną wagę przywiązywano do ich prawnego statusu. Zmiany w tym zakresie następowały powoli, nawet w środowiskach zorientowanych na niekonwencjonalną problematykę badawczą, jakim była szkoła Annales. Kobiety w pracach naukowców z tego kręgu były nadal niewidoczne. Dopiero trzecie pokolenie historyków związanych z tą szkołą, współtworzących od końca lat sześćdziesiątych XX w. tzw. nową historię (nouvelle histoire), nazywaną też historią mentalności, otworzyło się na historię kobiet.

Historiografia feministyczna rozwinęła się mniej więcej w tym samym czasie w Europie i w Ameryce, a po obu stronach Atlantyku w jej

${ }^{10}$ M. Bobako, Powrót kobiet do historii - niedokończony projekt?, www.ekologiasztuka.pl/think.tank.feministyczny (dostęp: 10.06.2012). 
awangardzie znalazły się historyczki i historycy zajmujący się antykiem, przede wszystkim greckim. Wybitna amerykańska intelektualistka Martha C. Nissbaum w uwagach o rozwoju women studies na amerykańskich uniwersytetach z pewną publicystyczną przesadą stwierdza, że

do roku 1975 w studiach klasycznych nie zgromadzono żadnych wiarygodnych świadectw dotyczących życia kobiet w świecie starożytnym

i za prekursorską uznaje wydaną w tym roku książkę Sarah Pomeroy Goddesses, Whores, Wives, and Slaves ${ }^{11}$. Wartości poznawcze tej i późniejszych prac Pomeroy o kobietach antyku różnie są dzisiaj przez historyków starożytności oceniane, ale nie ulega wątpliwości, że ta badaczka wykreowała pewien wzorzec ról przypisywanych kobietom w świecie starożytnym oraz model ich opisu. Te role to tytułowe: boginie, ladacznice, żony i niewolnice. Pomijając otwierający książkę rozdział o boginiach, pozostała część pracy jest skonstruowana chronologicznie. Wyobrażenie o treści pracy dają już tytuły rozdziałów: „Kobiety w epoce brązu i w epoce epiki homerowej”, „Wieki ciemne i epoka archaiczna”, „Kobiety i ateńska polis”, „Życie prywatne w Atenach epoki klasycznej”, „Obraz kobiet w literaturze klasycznych Aten”, „Kobiety hellenistyczne”, „Rzymskie matrony w późnej republice i wczesnym cesarstwie”, "Rola kobiet w religii Rzymian”. W przedmowie do drugiego wydania (1995) autorka tłumaczy, że zdecydowała się na taki zabieg, aby pokazać, że dzieje kobiet są częścią historii, a miejsce kobiety $\mathrm{w}$ społeczeństwie należy rozpatrywać $\mathrm{z}$ uwzględnieniem realiów konkretnej epoki i w powiązaniu z badaniami nad całym społeczeństwem antycznym. Tym samym Pomeroy włączyła dzieje kobiet w szeroko pojmowaną perspektywę społeczną, przyjmując, że chodzi nie tylko o życie prywatne kobiet, lecz także o ich miejsce w historii społecznej.

Martha Nissbaum podkreśla w cytowanej pracy, że studia starożytnicze wymagają specyficznych umiejętności, które „ma garstka ekspertów, a żaden z nich nie był na tyle zainteresowany życiem kobiet, by uczynić z niego cel badań”. Dalej kwestionuje użyteczność tradycyjnych technik

${ }^{11}$ M. C. Nissbaum, W trosce o cztowieczeństwo. Klasyczna obrona reformy ksztatcenia ogólnego, przeł. A. Męczkowska, Wrocław 2008, s. 202-229, zwłaszcza s. 215; S. Pomeroy, Goddesses, Whores, Wives, and Slaves. Women in Antiquity, New York 1975. 
badawczych służących do opisu życia kobiet, koncentrujących się wokół źródeł pisanych. Jej zdaniem potrzebna była kombinacja dwóch rzeczy: feministycznej optyki i znajomości warsztatu badacza starożytności, by można było pisać o kobietach tej epoki. Tego rodzaju spotkanie konieczne jest oczywiście w przypadku każdej innej epoki historycznej, ale starożytność ma szczególne wymagania warsztatowe związane nie tylko ze znajomością języków klasycznych, lecz także odmiennych od alfabetycznego systemów pisma (kliny, hieroglify), rodzajów źródeł (papirusy, inskrypcje) itp. Z diagnozą Nissbaum można oczywiście polemizować, ale sygnalizuje ona problem, wokół którego będzie się toczyło wiele późniejszych dyskusji, tzn. metodologii badań. Problem źródeł i metod ich interpretacji stał się pod koniec XX w. jednym z ważniejszych przedmiotów sporów wśród badaczy zajmujących się historią kobiet. Przedstawicielki (początkowo były to przede wszystkim kobiety) feministycznej historiografii uznały, że tradycyjna historiografia nie radzi sobie badaniami nad grupą społeczną, której głos jest w źródłach niewyraźnie odnotowany. Argumentowały, że wszystko, czym dysponujemy, aby poznać historię kobiet w minionych epokach, to wytwory mężczyzn, co stwarza trudność metodologiczną. We wprowadzeniu do krótkiego podręcznika prezentującego współczesny nurt badawczy, określany jako postkolonializm, można znaleźć interesujące uwagi na temat podobieństw między „postkolonialną analizą kulturową" podważającą ,zachodni sposób postrzegania rzeczywistości" a feminizmem krytykującym, by tak rzec, męski punkt widzenia na rolę kobiet:

Kiedyś każda książka, jaką można było przeczytać, każde przemówienie, jakie można było usłyszeć, każdy film, jaki się obejrzało, przedstawiały rzeczywistość z męskiego punktu widzenia. Istniało w niej miejsce dla kobiety, lecz w roli przedmiotu, a nie podmiotu. Zawsze okazywała się tą, na którą patrzono, nigdy zaś tą, która obserwuje. Przez stulecia przyjmowano, że kobiety są mniej inteligentne niż mężczyźni i nie zasługują na taki sam poziom wykształcenia [...]. Na tej samej zasadzie wszelkie rodzaje wiedzy rozwijanej przez kobiety traktowano jako niepoważne, trywialne, plotkarskie lub też jako wiedzę zdyskredytowaną przez naukę, na przykład przesądy lub tradycyjne praktyki porodowe czy lecznicze ${ }^{12}$.

${ }^{12}$ R. J. C. Young, Postkolonializm. Wprowadzenie, przeł. M. Król, Kraków 2012, s. 17. 
Czy w tej sytuacji historia kobiet w ogóle jest możliwa? To pytanie, postawione w latach siedemdziesiątych minionego wieku przez francuskie historyczki skupione wokół Michelle Perrot, nabrało symbolicznego znaczenia i w literaturze przedmiotu jest często przypominane. Oczywiście nie po to, aby kwestionować zasadność badań, ale jako rodzaj metodologicznej prowokacji ${ }^{13}$. Pod hasłem „czy historia kobiet jest możliwa?” odbyło się w 1983 r. sympozjum, uważane za akt fundacyjny francuskiej „historii kobiet”, której znakiem rozpoznawczym jest silny związek z antropologią kulturową. Perrot, w książce podsumowującej lata starań o uznanie studiów nad rolą kobiet w historii za pełnoprawną dyscyplinę akademicką, wspomina o długu, jaki historiografia ma wobec antropologii ${ }^{14}$. Wpływ tej dyscypliny jest trudny do przecenienia np. w studiach nad rodziną. Publikowane materiały ze wspomnianej wyżej konferencji wskazuja, że konieczność zastosowania metod antropologicznych do analiz historycznej rzeczywistości był akcentowany we wszystkich wystąpieniach. Antropologia występuje też w tytule tekstu Pauline Schmitt Pantel o różnicach między płciami w polis greckiej ${ }^{15}$.

Toczona pod koniec XX w. dyskusja zaowocowała nowymi tematami i nowym sposobem narracji. Zmiany następowały powoli, ale systematycznie. Przypomniałam wyżej zdania z tekstu Flacelière’a o sytuacji Atenek w czasach Peryklesa napisane w 1959 r. Trzydzieści lat później we Włoszech ukazał się zbiór artykułów pod tytułem Cztowiek Grecji. Znajduje w nim szkic Jamesa Redfielda Cztowiek i życie domowe, w którym znajdziemy kontynuacje rozważań Flacelière'a, ale język opisu jest już inny:

Wykluczenie kobiet $\mathrm{z}$ ateńskiego życia publicznego opiera się na zamkniętym kręgu przyczyn, tkwiących w samym systemie kultury. Dlaczego kobiety nie uczestniczą w życiu publicznym? Ponieważ nie są podmiotami mogącymi w nim uczestniczyć. Dlaczego nie są takimi pod-

13 Podobnie, jak pytanie: czy historia bez kobiet jest możliwa? Zob.: L'Histoire sans les femmes est-elle possible?, dir. A.-M. Sohn, F. Thelamon, Paris 1998.

${ }_{14}$ Une histoire des femmes est-elle possible?, dir. M. Perrot, Paris 1984; M. Perrot, Moja historia kobiet, przeł. M. Szafrańska-Brandt, Warszawa 2009, s. 16-18.

15 P. Schmitt Pantel, La différence des sexes: histoire, anthropologie et cité grecque, [w:] Une histoire des femmes est-elle possible?..., s. 98-119. 
miotami? Ponieważ podmiotowość nie należy się kobietom. Wyjściowe przesłanki wyznaczają ostateczną tezę ${ }^{16}$.

Redfield pisze dalej o ambiwalentnym statusie kobiet, o relacjach między kobietami i mężczyznami. W zaproponowanej przez autora analizie literackich wzorów żony odbijają się już metodologiczne dyskusje lat osiemdziesiątych. Zamyka ją uwaga o dopełniającym się świecie mężczyzn i kobiet:

Jeśli mężczyźni zastrzegali dla siebie sferę życia publicznego i całość tego, co nazywa się kulturą, to byli jednocześnie świadomi, że stanowi to jedynie połowę rzeczywistości. Każdej dychotomii - między życiem publicznym i prywatnym, męskim, żeńskim, kulturą i naturą - towarzyszy czynnik łączący, coś co pośredniczy ${ }^{17}$.

Za kamień milowy na drodze w myśleniu o historii kobiet uważa się publikację w latach 1990-1992, najpierw we Włoszech, a później we Francji, pięciotomowej Histoire des femmes en Occident (Historia kobiet na Zachodzie $)^{18}$. Było to ogromne przedsięwzięcie zrealizowane w międzynarodowym gronie prawie 80 autorów. Już w pierwszych recenzjach zwracano uwagę, że tytuł jest nieadekwatny do treści, która nie odpowiada koncepcji gatunku upowszechnionej przez Sarah Pomeroy. Zrezygnowano bowiem z układu chronologicznego na rzecz problemowego, a dobór tematów wskazywał, że redaktorzy, Georges Duby i Michelle Perrot, myśleli już w kategoriach relacji między kobietami i mężczyznami, a nie historii kobiet, jako odrębnej grupy. Pauline Schmitt Pantel, redaktorka tomu pierwszego (antycznego), napisała w krótkim wprowadzeniu, że męska dominacja w świecie antycznym i - co za tym idzie - podporządkowanie kobiet nie budzą wątpliwości, nie zwalnia to jednak badaczy z obowiązku poszukiwania odpowiedzi na pytanie o naturę wzajemnych relacji, zarówno

${ }^{16}$ J. Redfield, Cztowiek i życie domowe, [w:] Cztowiek Grecji, red. J.-P. Vernant, przeł. P. Bravo i Ł. Niesiołowski-Spanò, Warszawa 2000, s. 199.

17 Ibidem, s.222.

${ }^{18}$ Histoire des femmes en Occident, dir. G. Duby et M. Perrot, t. 1: L'Antiquité, dir. P. Schmitt Pantel, Paris 1991. 
w wymiarze prywatnym, jak i publicznym, oraz stawiania pytań o funkcjonowanie i znaczenie tych relacji w społeczeństwie. Wśród kwestii szczegółowych rozważanych w książce są np. pojęcie bogini w wyobrażeniach Greków, obecność kobiet w życiu polis, rola kobiet w religii rzymskiej czy podział płci w prawie rzymskim. Warto podkreślić, że autorki i autorzy tekstów zawartych w tomie dystansowali się od wyrosłej z kontestacji lat siedemdziesiątych historii kobiet, która bazowała na przekonaniu, że kobiety stanowią odrębną kategorię badawczą (tzn. mają odrębny status prawny, odrębne kulty, zajęcia, wyobrażenia itp.). Wbrew początkowym założeniom ujęcie to okazało się dla kobiet w pewien sposób wykluczające. Kobiety wprawdzie zyskały swoją własną historię, ale w ramach historii powszechnej został dla nich stworzony zamknięty świat historii kobiecej, toczącej się poza głównym nurtem zdarzeń. Tymczasem celem badań powinno być włączenie problematyki kobiet do podstawowych tematów badawczych współczesnej historiografii.

Część feministycznie zorientowanych historyczek (przede wszystkim amerykańskich) nie godziła się jednak na odejście od historii kobiet ściśle zdefiniowanej jako odrębnej dyscypliny. Konsekwencją tej sytuacji jest, ujmując rzecz w dużym uproszczeniu, ukształtowanie się dwóch modeli badawczych. W ramach obydwu studiuje się oczywiście relacje między płciami, ale Amerykanki preferują jednak rozwijanie historii kobiet jako sektora autonomicznego. Źródła tych odmienności tkwią zarówno w odmiennościach francuskiego feminizmu, jak i w tradycji niektórych nurtów historiograficznych, nad Sekwaną silnie związanych z naukami społecznymi. W zakresie studiów starożytniczych jest to szczególnie widoczne ${ }^{19}$.

${ }^{19} \mathrm{O}$ odmiennościach francuskiego feminizmu i historii kobiet jako swego rodzaju nurcie intelektualnym traktuje znakomita praca M. Solarskiej i M. Bugajewskiego, Wspótczesna francuska historia kobiet. Dokonania - perspektywy - krytyka, Bydgoszcz 2009; materiały z dyskusji poświęconej tej książce opublikowano w „Klio. Czasopiśmie poświęconym dziejom Polski i powszechnym" 2011, t. 19, nr 4, s. 155-192; http://dx.doi. org/10.12775/KLIO.2011.061. Pewne wyobrażenie o antropologizujących nurtach w historiografii francuskiej daje wybór tekstów: Antropologia antyku greckiego. Zagadnienia i wybór tekstów, oprac. W. Lengauer, L. Trzcionkowski, P. Majewski, red. W. Lengauer, L. Trzcionkowski, Warszawa 2011. Niestety nie ma w tym zbiorze tekstów dotyczących 
Powściągliwość w posługiwaniu się pojęciem „historia kobiet” jest też konsekwencją stopniowego przystosowywania do potrzeb badań historycznych koncepcji gender.

Gender, jako użyteczne narzędzie analizy, pojawia się w naukach historycznych w połowie lat osiemdziesiątych. W naukach społecznych fundamentem teorii gender jest przekonanie, że poza zdeterminowaną przez naturę płcią biologiczną istnieje też „płeć kulturowa/społeczna” zdeterminowana przez kulturę ${ }^{20}$. Ta druga zmienia się w zależności od miejsca i czasu, a więc powinna być badana za pomocą metod właściwych naukom historycznym. Przedmiotem analiz są role, które płci przypisuje społeczeństwo, i sposób, w jaki to przypisanie następuje, ponieważ są to pochodne organizacji społecznej. W tym przypadku mamy jednak do czynienia ze zjawiskiem sprzężenia zwrotnego - role płciowe są konstruowane społecznie, ale wpływają też na organizację i funkcjonowanie społeczeństwa. Punktem wyjścia dla historyka odwołującego się do kategorii gender jest z pozoru banalna teza, że społeczeństwo składa się z kobiet i mężczyzn, ale jeżeli nacisk przeniesiemy z płci biologicznej na kulturową, rzecz stanie się bardziej skomplikowana. Najprościej rzecz ujmując, gender w historiografii to metoda opisu relacji między kobietami i mężczyznami uwzględniająca wymienione wyżej założenia.

Konsekwencją zastosowania tej metody jest rozróżnianie praktyk seksualnych, wynikających chociażby z orientacji seksualnej, od ról seksualnych, które są konstruktem kulturowym, ponieważ to społeczeństwa (kultura) przypisują je kobietom i mężczyznom. Interpretacja tych drugich wymaga wyjaśnienia, kogo dana kultura uważa za kobietę, a kogo za mężczyznę i na podstawie, jakich cech (np. odwaga, waleczność to cechy męskie, opiekuńczość, emocjonalność - żeńskie itp.). Każda z płci ma swoją rolę do odegrania, ale obie są od siebie zależne.

Dzięki gender wiemy, że każde odejście od ustalonych ról jest uważane za transgresję (np. „męska kobieta” i „zniewieściały mężczyzna”) i staje się źródłem napięć, które odnotowują źródła, jeżeli się je uważnie analizu-

bezpośrednio kobiet; por.: D. Musiał, [rec.], „Przegląd Humanistyczny” 2012, nr 4, s. $123-128$.

${ }^{20}$ H. Bradley, Pteć, przeł. W. Chomicka, Warszawa 2009, s. 11. 
je. Wiele ciekawych opowieści ilustrujących postrzeganie zmienności ról płciowych zawierają Dzieje Herodota. Nie ulega wątpliwości, że kultura grecka uważała dzielność i odwagę za cechy wybitnie męskie, w literaturze znajdziemy aż nadto przykładów potwierdzających to przekonanie, oczywiście także u Herodota. Do największych czynów byli zaś zdolni „prawdziwi mężczyźni”, czyli ci, którzy odznaczali się piękną duszą w szlachetnym silnym ciele ${ }^{21}$. Herodot nie kryje zdziwienia, kiedy dowiaduje się, że mieszkańcy miasta Gela na Sycylii jednego ze swoich przodków, który przyczynił się do świetności miasta, wspominają jako zniewieściałego i miękkiego człowieka (VII, 153). Z tekstu nie wynika, aby te cechy pozbawiły go szacunku czy w oczach rodaków pomniejszyły jego dokonania. Stało się tak być może dlatego, że - jak wyjaśnia Herodot - ów człowiek nie był wojownikiem, ale kapłanem.

W innym miejscu grecki historyk opowiada historię o tym, co z mężczyzny czyni kobietę. Kiedy Cyrus zamierzał ukarać buntujących się mieszkańców Sardes, Krezus, chcąc ocalić miasto, zaproponował królowi perskiemu takie oto rozwiązanie:

Lidyjczykom przebacz i zarządź u nich, co następuje - żeby ani się nie buntowali, ani ci nie grozili [...] zakaż im nabywać broń wojenną; rozkaż, żeby pod wierzchnie szaty wdziewali chitony i obuwali się w koturny; dalej zaleć im kształcić dzieci w grze na cytrze, w tańcu i w kramarstwie. I rychło, królu ujrzysz, jak z mężów staną się niewiastami (I, 155, przekł. S. Hammer).

Z dalszych zdań wynika, że stało się tak, jak chciał Krezus, i mieszkańcy Sardes całkowicie zmienili swoje życie. Niebezpieczeństwo buntu zostało zażegnane, ponieważ potencjalni buntownicy przestali być mężczyznami, a widocznym znakiem tej przemiany była utrata przez nich podstawowej męskiej cechy - odwagi.

I ostatni przykład zaczerpnięty z dzieła Herodota, być może najsławniejsza „genderowa” historia opowiedziana przez tego greckiego historyka,

${ }^{21}$ Por.: teksty zawarte w tomie: When Men were Men. Masculinity, power and identity in classical antiquity, ed. L. Foxhall, J. Salmon, London 1998. 
na pewno zaś najczęściej cytowana w literaturze przedmiotu ${ }^{22}$. Tym razem mamy do czynienia z zamianą ról w drugą stronę, spotykamy bowiem kobietę wojowniczkę, ale nie wojowniczkę mityczną, jak Amazonki, tylko postać historyczną, Artemizję z Halikarnasu. Opisane przez Herodota wydarzenia są związane z wojnami grecko-perskimi, a dokładnie z wyprawą Kserksesa w 480 r. p.n.e. i bitwą pod Salaminą. Po stronie perskiej brały w niej udział eskadry okrętów z greckich miast Azji Mniejszej. Pięć okrętów wystawionych przez Halikarnas przyprowadziła do Grecji Artemizja, która po śmierci męża rządziła miastem, chociaż, jak podkreśla Herodot, miała syna. Historyk nie kryje podziwu dla tej kobiety (gyné), która „jawi mu się jako prawdziwie cudowna” (VII, 99), ponieważ towarzyszyła Kserksesowi powodowana odwagą. W tym miejscu relacji Herodota pojawia się słowo andrêiê, o jednoznacznym wydźwięku - jest to męska odwaga ${ }^{23}$. Król perski miał zaufanie do wojskowych talentów Artemizji i słuchał jej rad w kwestiach taktycznych. Jak wiadomo, starcie z flotą ateńską Persowie przegrali, ale zdaniem Herodota, rozgoryczony Kserkses, będąc pod wrażeniem postawy Artemizji podczas bitwy, miał powiedzieć do swego otoczenia:

Mężowie (andres) stali się u mnie kobietami (gunaikes), a kobiety mężami (gunaikes andres) (VIII, 88).

W tej relacji jest jeszcze jedna ciekawa informacja, tym razem związana z Ateńczykami, którzy wykazali się w bitwie. Herodot wspomina o jednym z nich, który ścigał okręt Artemizji, ale poniechał pościgu, ponieważ nie wiedział, z kim ma do czynienia. Gdyby wiedział, wolałby dostać się do niewoli niż poniechać pościgu, ponieważ wyznaczono nagrodę

${ }^{22}$ V. Sebillotte Cuchet, Hérodote et Artémisia d'Halicarnasse. Deux métis face à l'ordre des genres athénien, „Clio. Histoire, femmes et sociétés” 2008, no. 27, http://clio.revues. org/7303 (dostęp 3.01.2013); http://dx.doi.org/10.4000/clio.7303, tam też szczegółowa bibliografia.

${ }^{23}$ S. E. Harrell, Marvelous "andreia”: politics, geography, and ethnicity in Herodotus' Histories, [w:] Andreia. Studies in manliness and courage in classical antiquity, ed. R. M. Rosen, I. Sluiter, Leiden-Boston 2003, p. 77-94. 
dziesięciu tysięcy drachm dla tego, kto ją żywcem pojmie: tak bardzo byli oburzeni, że kobieta wyruszyła przeciw Atenom.

Nagroda była wysoka i zapewne adekwatna do sławy, jaką Artemizja cieszyła się wśród Greków.

Inną konsekwencją zastosowania metody genderowej jest podważenie dominującej przez znaczną część XX w. tezy o ścisłej separacji w świecie antycznym sfery publicznej i prywatnej. Georg G. Iggers (historyk daleki od entuzjazmu wobec historiografii feministycznej) w uzupełnieniu do swojej Historiografii XX wieku pisał:

Coraz bardziej odchodzi się też od ścisłego rozdziału sfery prywatnej i publicznej. Praktykowany przez tradycyjną historiografię, podział ten za istotną historycznie uważał zdominowaną przez mężczyzn sferę publiczną, lekceważąc codzienne życie kobiet w domu i miejscu pracy jako historycznie bez znaczenia ${ }^{24}$.

Źródła potwierdzają, że aktywność publiczna była generalnie związana z mężczyzną (obywatelem) i to zwykle określa się mianem sfery publicznej, podczas gdy kobiety rządziły sferą domową - „oikoidalną” - jak to się czasem nazywa, posiłkując się greckim terminem oikos oznaczającym gospodarstwo. I to właśnie tę sferę uważa się zwyczajowo za prywatną. Wnikliwa analiza świadectw pokazuje, że w praktyce społecznej, religijnej, ekonomicznej, a nawet prawnej obie sfery nie musiały być przeciwstaw$n \mathrm{e}^{25}$. Współczesne definicje tego, co jest publiczne, i tego, co jest prywatne, odbiegają bowiem od realiów świata antycznego. Jeżeli weźmie się ten fakt pod uwagę, nieco inaczej wygląda kwestia wykluczenia kobiet z życia publicznego. Dobrym przykładem, ilustrującym dyskusję na ten temat, jest kwestia funkcji religijnych pełnionych przez kobiety zarówno w polis greckich, jak i w Rzymie. Bez wątpienia funkcje te należały do sfery publicz-

${ }^{24}$ G. G. Iggers, Historiografia XX wieku, przeł. A. Gadzała, Warszawa 2010, s. 105.

${ }^{25}$ Ciekawe uwagi na ten temat: H. Derks, Un Mal Splendide: hommes et femmes dans une „Antiquité postféministe”, „Dialogues d'histoire ancienne” 2011, no. 27, s. 7-43; http://dx.doi.org/10.3406/dha.2001.2447. 
nej ${ }^{26}$. Uświadomienie sobie tego faktu znacznie poszerzyło pola badawcze. Źródła archeologiczne pozwoliły uzupełnić wyobrażenia na temat życia kobiet antycznych o bardzo istotne elementy. Z inskrypcji (wotywnych, honoryfikacyjnych) wyłania się inny obraz niż znany ze źródeł literackich. Spotykamy w nich kobiety - aktywne uczestniczki życia publicznego i nie zawsze są to hellenistyczne królowe bądź rzymskie cesarzowe. Kobiety były oczywiście kapłankami, ale również ambasadorkami wybieranymi przez polis do pełnienia misji specjalnych, zarządzały dobrami ziemskimi, prowadziły rozległe interesy, sponsorowały budowle publiczne i organizację różnych uroczystości ${ }^{27}$.

Badacze antyku zawsze bardziej niż znawcy innych dziedzin historii zainteresowani byli antropologią ${ }^{28}$. Dzisiaj też chętnie sięgają po nowe tematy, które zyskały na znaczeniu dzięki zmianom w historiografii, takie jak: emocje, ciało, seksualność itp. Ich realizacja jest oczywiście niemożliwa bez wypracowania nowych metod interpretacji źródeł literackich. Kluczową kwestią w tym zakresie jest ustalenie, jak starożytni postrzegali samych siebie i jakiego aparatu pojęciowego używali do opisu swoich pragnień i emocji, swoich relacji z innymi i z innością ${ }^{29}$. Trudność polega na tym, że do dyspozycji mamy teksty, o których nie wiemy, czy odzwierciedlają

${ }^{26} \mathrm{O}$ adaptacji gender do badań nad religią rzymską: A. Gillmeister, Foucault i matrony. Kobiety $w$ religii rzymskiej: między „potestas” a „potentia”, „Klio. Czasopismo poświęcone dziejom Polski i powszechnym" 2013, t. 24, nr 1, s. 3-16; http://dx.doi.org/10.12775/ KLIO.2013.001.

${ }^{27}$ Już w XXI w. ukazało się na ten temat wiele publikacji, tytułem przykładu warto wspomnieć: A. Bielman, Femmes en public dans le monde hellenistique, Paris 2002; Les femmes antiques entre sphère privée et sphère public, dir. R. Frei-Stolba, A. Bielman, O. Bianchi, Bern 2003.

28 Obszerne wskazówki bibliograficzne dotyczące wykorzystania metodologii gender w badaniach nad światem antycznym zawierają prace: Problèmes du genre en Grèce ancienne, dir. V. Sebillotte Cuchet, Paris 2007; Hommes et les femmes dans l'antiquité grecque et romaine. Le genre: methode et documents, dir. S. Boehringer, V. Sebillotte Cuchet, Paris 2011.

${ }^{29}$ Literatura $\mathrm{z}$ tego zakresu jest już bardzo bogata, np.: F. Santoro LHoir, The Rhetoric of Gender Terms: "Man”, "Woman”, and the Portrayal of Character in Latin Prose, Leiden 1992; M. Gleason, Making men: sophists and self-presentation in ancient Rome, Princeton 1993; T. Späth, Männlichkeit und Weiblichkeit bei Tacitus. Zur Konstruktion der Geschlechter in der römischen Kaiserzeit, Frankfurt am Main-New York 1994. 
rzeczywiste poglądy konkretnych ludzi bądź grup, czy są wykreowaną przez ich autorów abstrakcją zależną od gatunkowych konwencji. Zawsze badano rolę stereotypu w tekstach, ale w przeszłości rzadko pytano o stereotypowe role męskie czy kobiece, nie szukano u autorów antycznych ich wyobrażeń o męskości i kobiecości.

Paweł Dybel we wstępie do Zagadki „drugiej ptci”, tłumacząc znaczenie problematyki gender dla dyskusji o człowieku i kulturze, zwraca uwagę, że sceptycznie do niej podchodzą

badacze o nastawieniu historycznym, zajmujący się głównie wybranymi epokami z przeszłości kultury europejskiej i niejako z założenia krytyczni wobec intelektualnych nowinek i mód współczesności ${ }^{30}$.

Wiele w tym stwierdzeniu racji. Studia genderowe długo były przez wielu historyków traktowane jako intelektualna moda niewiele wnosząca do naszej dyscypliny. Zniechęcał też brak perspektywy historycznej widoczny w wielu pracach zaliczanych do nurtu gender, co utrudniało akceptację założenia, że studia nad przypisanymi każdej płci rolami należą do historii społecznej. Powoli zaczynamy jednak mówić i pisać o wzajemnym oddziaływaniu. Studia genderowe uwrażliwiają historyków na nowy typ refleksji i wzbogacają analizy we wszystkich obszarach historii, z czego chętnie korzystają starożytnicy ${ }^{31}$.

30 P. Dybel, Zagadka „drugiej ptci”: spory wokót różnicy seksualnej w psychoanalizie i $w$ feminizmie, Kraków 2012, s. 29-30.

31 Stopniowo również polskie badania wzbogacają się o prace poszerzające naszą wiedzę o rozumieniu kobiecości i męskości w świecie antycznym. Ostatnio: L. Kostuch, Uzbrojona bogini. Żeńskie bóstwa wojenne w historii starożytnych Greków, Kielce 2012, czy A. Kompa, Kobieta rzymska, kobieta bizantyńska - co studia klasyczne moga zaoferować dzisiejszym gender studies, [w:] Kobiety i wtadza w czasach dawnych, Katowice [w przygotowaniu]. 


\section{Woman and man in the ancient world: comments on old disputes and new expectations}

(Summary)

The article has a purpose to draw attention to discussions which have started in the seventies of the last century. These discussions have led to creating two ways of writing about women's role in the ancient world: American and French. In the first model, "women history" is treated as an autonomic research discipline. Strong relationships with cultural anthropology and research concentrated on relationships between women and men are characteristic for the second model. Utilising gender theory in research about women's roles in the graeco-roman world allowed highlighting new areas (outside the private sphere) in which women were active.

Danuta Musiał Instytut Historii i Archiwistyki, Uniwersytet Mikołaja Kopernika dmusial@umk.pl 